УДК 726.54(497)(049.3)

https://doi.org/10.55302/MF2077-78293ach

Емилија Апостолова-Чаловска

\title{
ЦРКВАТА „РОЖДЕСТВО НА ПРЕСВЕТА БОГОРОДИЦА“ ВО \\ ТЕПАВЦИ КАКО ПОСТВИЗАНТИСКИ АНТЕЦЕДЕНТ НА ПРЕРОДБЕНСКИТЕ ТРИКОРАБНИ БАЗИЛИКИ
}

\begin{abstract}
Апстракт: Преродбенскиот XIX век ќе го одбележи ренесанса на целокупното општество во Отоманската Империја, со сите негови манифестации, вклучително и архитектурата и сродните дисциплини. Во духот на романтичарските движења карактеристични за овој период, за кои е својствено навраќање кон минати, славни епохи од историјата, во архитектурата, односно во сакралното градителство на територијата на Македонија ќе се одвива процес на „возобновување“ на одамна напуштено типолошко решение - трикорабната базилика. Имено, масовната изградба на трикорабни базилики се поврзува со владеењето на Самуиловата држава (X-XI век), по што, во сакралната архитектура, сѐ до преродбата, ќе доминираат сосем поинакви типолошки решенија и обрасци. Во тој контекст, од исклучително значење се неколку архаични трикорабни базилики изградени во поствизантискиот период, односно XVI - XVIII век, кои претставуваат нишка што ги поврзува средновизантиските и преродбенските трикорабни базилики, градени по нивен узор осум века подоцна. Таков пример е црквата „Рождество на Пресвета Богородииа“, во селото Тепавци (Битолско, Мариово) од 1767, а живописана во 1795 година. Овој труд се осврнува на нејзината архитектура, архитектонска типологија, конструкција и декорација, во насока на расветлување на влијанијата под кои настанала, како и нејзиното влијание врз подоцнежните преродбенски трикорабни базилики.
\end{abstract}

Клучни зборови: трикорабна базилика, столпци, полуцилиндричен свод.

Селото Тепавци, познато и како Теповци, географски припаѓа на битолскиот дел од областа Мариово. Се простира во југоисточниот дел на Битолско Поле, на надморска височина од $750 \mathrm{~m}$, во рамнинско-ридско подрачје од левата страна на Црна Река и зафаќа атар од 12,3 km², административно припаѓа на Општина Новаци, од чиј центар (селото Новаци) е оддалечено $12 \mathrm{~km}$, а од градот - Битола $23 \mathrm{~km}$. Во Тепавци има две цркви: гробишната црква „Рождество на Пресвета Богородица“ и манастирската црква „Св. Архангел Михаил“, која датира од преродбата.

Црквата „Рождество на Пресвета Богородица“ во Тепавци (сл. 1а) е изградена во 1767 година, а била живописана нешто подоцна, во 1795 година, за што дознаваме од натписот на грчки јазик, насликан над северната влезна врата во наосот. Според годината на изградба, црквата во Тепавци припаѓа на поствизантиската сакрална архитектура, градена во рамки на Отоманската Империја, чие владеење ќе наметне целосна стагнација на црковното градителство, пред сѐ, како резултат на државната политика на маргинализирање на христијанството и на неговите институции, законските ограничувања за изградба на нови и обновување на старите храмови (Ѓорѓиев, $2013,1911)$, а секако и како последица на значителното намалување на 
економската моќ на потенцијалните ктитори. Имено, додека во претходните епохи ктитори на позначајните цркви и манастирските комплекси се, не само претставници на локалната власт и прелатите на Охридската архиепископија, туку дури и членови на византиското императорско семејство, по Отоманската окупација, градбата на нови црковни објекти, како и одржувањето на постоечките - оние што не биле разрушени во воените судири или одземени и конвертирани во џамии - ќе падне на товар на локалното христијанско население.

Како резултат на овие прилики, единствено се градат цркви во руралните средини, каде што доминира христијанско население и каде што османлиската власт е потолерантна кон неговите верски потреби, како и во манастирите изолирани во потешко достапни планински региони. Помасовна изградба на цркви и манастири може да се проследи во XVI-XVII век, по запирањето на експанзионистичките политики на Империјата и стабилизирањето на нејзиното внатрешно уредување. Сепак, христијанската сакрална архитектура ја губи монументалноста карактеристична за претходните епохи: поствизантиските цркви се малечки, најчесто еднокорабни градби засводени со полуцилиндричен свод, градени од кршен камен, некаде и со употреба на тула, со една, вообичаено тристрана или полукружна олтарска апсида. Покривани се редовно со двоводен покрив, традиционално од камени плочи, кои денес најчесто се среќаваат фрагментарно сочувани над олтарските апсиди. Кај голем дел од овие цркви дополнително бил доградуван нартекс, трпезарија или трем, додека автентично немале придружни простории. Ги карактеризира отсуство на надворешна фасадна декорација и скромно внатрешно уредување, ретко со присуство на резбани елементи - певници, царски двери, иконостас (К̈орнаков, 1987, 14) но, според сѐ уште доследно спроведуваните византиски канони, имаат целосно фреско-живописан ентериер.

Имајќи ги предвид општествените околности во кои настанала и следствено типот на архитектонско творештво, кој, во тој период, преовладувал, црквата „Рождество на Пресвета Богородица“ е навистина уникатен и неверојатно значаен споменик. Иако е изградена седумдесетина години пред сеопфатните општествени промени, кои ќе го дефинираат преродбенскиот период, оваа црква претставува вистински предвесник на преродбенското монументално сакрално градителство.

\section{Архитектура}

Црквата „Рождество на Пресвета Богородица“ во Тепавци претставува трикорабна базилика со значително големи димензии и благо неправилна, трапезна основа, која се шири од запад кон исток (сл. 3). Вкупните димензии на објектот изнесуваат 17,75 m должина (19 m, вклучувајќи ја олтарската апсида) и $11 \mathrm{~m}$ широчина на храмот, односно неговиот пропорциски сооднос изнесува 1:1,6. До наосот, подоцна се доградени затворени тремови од северната и од западната страна, во облик на „Г““. 
Пространството на наосот е разделено на три кораби со помош на два реда од по пет масивно зидани столпци со пресек 80-90/100 cm (сл. 2a, 3). Бочните кораби се потесни, односно нивната широчина варира околу $2 \mathrm{~m}$, додека распонот од средишниот брод се движи околу $3 \mathrm{~m}$. Така, соодносот на распоните на централниот наспроти бочните бродови изнесува $1: 1,5$, па дури и помалку, ако се земе предвид проширувањето на северниот бочен кораб од запад кон исток. Височината во внатрешноста на црквата изнесува 5,6 m во централниот, а 4,7 m кај бочните кораби, односно разликата во височина меѓу корабите изнесува само $90 \mathrm{~cm}$. Следствено, може да се каже дека во основа, како и во пресек, централниот кораб не е особено нагласен во споредба со бочните, односно наосот е прилично рамномерно поделен на три кораби. Столпците, кои ги раздвојуваат меѓу себе, се поврзани со полукружни лаци и лаци со потковичест пресек, така што формираат две аркадни низи (сл. 2a). Наместо капител, преодот од столбец во лак е означен со едноставна правоаголна профилација. На запад, последниот пар столпци е поврзан со лаци со соодветен пар масивни пиластри (сл. 16, 3), додека на исток лаците директно удираат во источниот sид, без да се потпрат на конзоли ниту пиластри. Во напречен правец целиот систем е вкрутен со дрвени затеги, кај пониските бочни бродови со по една, додека во централниот брод со по две, поставени на две нивоа (сл. 1б), што е овозможено од неговата поголема височина. Трите брода се премостени со полуцилиндрични сводови, а на исток завршуваат со три одвнатре и однадвор полукружни апсиди, без расчленување ниту слепи ниши (сл. 3, 6а). Единствено средишната поголема апсида првично имала тесен прозорец - монофора, кој подоцна бил пополнет со сувоsид. Како единствен декоративен елемент во нивната надворешна обработка, апсидите во горната зона поседуваат профилиран завршен венец, исто така малтерисан. Дополнителна плитка полукружна ниша во олтарот е изведена во северниот sид, односно во просторот на проскомидијата.

За разлика од современите поствизантиски црквички, кои се целосно масивно градени, вклучително и сводните партии, кај црквата во Тепавци веќе го среќаваме комбинираниот конструктивен систем, кој ќе ја одбележи сакралната архитектура на следниот, XIX век. Така, додека носечките столпци и ободните мидови, чија дебелина варира од 85 до $95 \mathrm{~cm}$, се градени масивно од кршен и приделкан камен и слоеви за израмнување во вид на дрвени решетки (сл. 1a), а потоа премалтерисани, сводовите се изведени од лесна дрвена конструкција, сочинета од дрвени греди, летвички и штички обложена со малтерни премази и фреско-живопис, односно станува збор за т.н. „лажни“ сводови (сл. 1б, 2б).

Покрај ова типично преродбенско структурно решение, мноштво други нејзини карактеристики ја потврдуваат нејзината улога како антецедент на преродбенската црковна архитектура. Така, црквата во Тепавци и покрај значителните димензии, е прекриена со еден целосен и нестепенуван двоводен покрив (сл. 1a, 6a), со дополнителни две кратки води на западната и источната фасада, со што тие добиваат трапезна форма, специфична за преродбенските 
цркви. ${ }^{1}$ Денес, покривот е покриен со ќерамиди, но автентичниот кровен покривач од камени плочи сѐ уште се среќава кај олтарските апсиди. На, инаку, едноличните малтерисани фасади се издвојуваат прозорските рамки како и влезните портали, изведени во делкан камен (сл. 1a).

Постојат дури три влезни портали, еден централно поставен западен влезен портал и два бочни, во симетрична композиција, кои соодветствуваат на вториот распон меѓу столпците (сл. 3). Оваа диспозиција на влезните портали, како и стратиграфијата на фасадите, ни зборуваат за првично постоење на тремови од сите три страни на наосот, односно во вид на „П“. Над влезните портали (освен јужниот) е оформена лачно засводена ниша за фреска на патронот на црквата, каква што редовно среќаваме кај преродбенските цркви. Високо на источната и на западната фасада се сместени прозорски отвори со транзени од камена пластика (сл. 6а) во вид на фитоморфен мотив - четирилисна детелина, односно крст обликуван како цвет со четири латици (т.н. crux florida). Покрај овие два декоративно обработени прозорци и малата монофора во олтарската апсида, наосот на црквата е осветлен преку два симетрично поставени правоаголни прозорци на западната фасада, четири на јужната (сл. 1a), а само еден на северната фасада.

Сепак, за разлика од преродбенските базилики, кај црквата во Тепавци отсуствува галерија (т.н. „женска црква“) во западниот дел од наосот (сл. 1б, 3), а може да се претпостави дека родовата сегрегација на верниците се одвивала на едно ниво, во бочните бродови од наосот, како што впрочем е случај и кај постарите, ранохристијански и византиски базиликални храмови.

\section{Иконостас}

Олтарниот простор на црквата во Тепавци, како и кај другите современи храмови, е разделен од наосот со помош на олтарна преграда, поставена на западната страна од последниот источен пар столпци (сл. 2б). Како мошне невообичаено решение, олтарната преграда лежи директно на подот од наосот, односно не постои редовната денивелација во вид на трибина, постапка што овозможувала визуелно и физичко издвојување на олтарот. И покрај монументалните димензии на црквата во Тепавци, во олтарот се влегува само преку царските двери и една бочна врата - во северниот брод (односно проскомидијата), а отсуствува директна врска со ѓакониконот. Иконостасот е работен во дрво, без релјефна резба, со богато нијансирање и сликана декорација на неговите елементи со крстовидни и флорални мотиви (дрво на животот, вазни со цвеќе, ластари, букети и поединечни цветови) во топли црвени, теракота, окер, зелени и сини тонови. Според еден сочуван натпис од долната зона, дознаваме дека е изведен во 1890 година, што не наведува да претпоставиме дека првично, при живописувањето на црквата од 1795 година, бил изведен постар автентичен иконостас, кој од некоја причина бил заменет

\footnotetext{
1 Ова решение ќе придонесе подоцна овој тип на базилики да бидат наречени "hallenkirche", односно цркви - хали, термин за прв пат употребен од германскиот историчар на уметноста Wilhelm Lübke, кон средината на XIX век.
} 
со постоечкиот, безмалку сто години подоцна. За постариот иконостас ни сведочат доста оштетени постари икони, кои денес се чуваат во црквата (сл. 2б).

Денешниот иконостас се развива во две зони: прва зона - зона на престолни икони поставена над цокле од дрвени панели со ромбовидни профилирани апликации и втора зона - зона на помали икони, кои се поставени во два реда. Двете зони се разделени со насликана греда космитис. Во бочните бродови, вториот ред на горната зона е прекинат на средината со цел да се остави место за крст - распетие, чии краци завршуваат во суптилно тролисно проширување (во јужниот брод со додадени ромбовидни елементи), а кој почива на две спротивставени крилести ламји. Во централниот брод втората зона е комплетна, а распетието е поставено врз вториот ред икони, што е овозможено од неговата поголема височина. Централното распетие (т.н. змиски крст) е подекоративно, пораскошно обработено, со трилисно проширени краци, акцентирани со дополнителни елементи, пластично обликувани во вид на дабови ливчиња. Го фланкираат засебни ќитабиња, ${ }^{2}$ поставени врз опашките на ламјите, кои го носат крстот во своите челусти, како и странично поставени соларни - sвездени мотиви. Иконостасот, како впрочем и самата црква, е доста оштетен, така што северната половина од овие придружни елементи денес недостасува.

\section{Живопис}

Живописот на црквата во Тепавци е изведен во два наврати, односно може да се идентификуваат најмалку два слоја. Постариот слој секако му припаѓa на првичниот сликарски ансамбл од 1795 година, кој, судејќи по споменатиот натпис на северниот sид, може да им го припишеме на автори од Епирскиот културен ареал, ${ }^{3}$ за кои знаеме дека често работеле во Крушевскиот и во Битолскиот Регион, а и пошироко. Двете фази на живопис се проследуваат и според употребениот јазик, така што наместа е оставен автентичен текст на грчки, додека наместа е евидентно негово дополнително прекривање со словенски сигнатури. Ова второ сликање на црквата може да се доведе во врска со изработката на вториот, понов иконостас, односно една посеопфатна обнова на ентериерот на црквата, изведена при крајот на XIX век, стотина години по нејзината изградба и по првично декорирање. Присуството на сигнатури и натписи на две писма (грчко и словенско) е резултат, пред сѐ, на општествените услови во периодот од кој датираат двете сликарски фази кај црквата во Тепавци. Така, првиот слој живопис настанува по укинувањето на Охридската архиепископија во 1767 година (Снегаров, 1946, 340-341), чин по кој надлежна верска институција за регионот ќе биде

\footnotetext{
${ }^{2}$ На страничните ќитабиња се претставени плочите со десетте Мојсиеви заповеди, запишани со римски броеви на бела основа.

${ }^{3}$ Или пак станува збор за сликари со влашко потекло, што исто така може да се врзе со Епирскиот Регион, од каде што, како што е познато, Власите мигрирале во Македонија токму во XVIII - XIX век.
} 
Цариградската патријаршија, чиј официјален јазик е грчкиот. Вториот слој живопис, пак, ќе настане кон крајот на следното столетие, по формирањето на Бугарската егзархија во 1870 година (Kiel, 1985, 230), која релативно брзо ќе го прошири своето влијание на територијата на Македонија, вклучително и во областа Мариово.

Живописот кај црквата во Тепавци е застапен на западниот sид од наосот, во олтарот, на источната половина од сводот во централниот брод, како и на средишните аркадни низи. Преостанатите површини се насликани во вид на стилизирано звездено небо сочинето од издолжени шестокраки sвезди во златножолта нијанса врз заднина со син тоналитет (сл. 16, 2). Sвездите се погусто насликани на сводовите, но преоѓаат и на вертикалните површини, односно на зидовите, па дури и на столпците, чие дно е обоено во потемен син тон, во вид на ниско цокле. Покрај ьидните и сводните површини, во истата небесносина боја биле обоени и дрвените затеги, што придонесува, заедно со богатата колоритност на иконостасот, кон исклучителна живописност.

Според каноните, на ободните sидови над седиштата наменети за верниците се насликани светители ${ }^{4}$ и свети воини во цел раст (сл. 2б). Во централниот брод, во зоната на преод од вертикална во засводена површина, се поместени сцени од житието на Христ и Богородица, односно композиции од големите празници, додека под нив, во зоната над лаците и меѓу нив се насликани светители во засебни медалјони и помали сцени (сл. 2a), а светители во цел раст се насликани и на самите лаци. Во темето на сводот во централниот брод сосем фрагментарно се сочувани три големи мандорли, какви што вообичаено среќаваме кај засводените базилики, како замена за слепи или целосно надвишени куполи. Во овие мандорли вообичаено биле сликани: Св. Трочиа, Христ Пантократор и Богородица Ширшаја, од која е делумно сочувана сигнатурата. На западниот sид се развива комплексната композиција Страшниот суд (сл. 1б). Во конхата на апсидата, како што е вообичаено, е насликана Богородица Ширшаја во став на Оранта, со Христ во кружна мандорла во нејзиниот скут, додека под неа е насликан фриз со три медалјони со претстави на светители (св. Григориј Богослов, св. Јован Златоуст и св. Василиј Велики), чие редовно присуство во конхата се поврзува со нејзината основна евхаристично-литургиска намена, вообичаено претставена преку композицијата Поклонувањето на архиереите, опкружени со богата барокно извиена флорална орнаментика во вид на ластари од винова лоза и гроздови. Над самата конха е насликан ликот на Христ на развиорен покров, кој го носат четири ангели во лет. Од обете страни на високо поставениот прозорец над апсидата, насликана е композицијата Благовештение. Во проскомидијата и ѓакониконот продолжува да тече фризот со светци во кружни медалјони, под кој се протега лента со богата флорална орнаментика - разгранети ластари со рози во вид на барокни „S-волути“. Фрагменти од фрески се сочувани и во самите прозорски отвори (сл. 2б).

\footnotetext{
${ }^{4}$ Меѓу останатите, се среќава и претстава на сесловенските просветители Кирил и Методиј, како обележје на значаен, силен локален култ.
} 
За жал, сликарскиот ансамбл на црквата во Тепавци е мошне оштетен: евидентни се длабоки пукнатини, потклобучување на малтерот, отпаднати делови особено од сводовите, каде што наместа е изложена дрвената сводна конструкција, а честопати и самата таа е срушена (сл. 1б, 2б). Досега не се преземени мерки за негово чистење и реставрација, така што е невозможно да се проучи во целост.

Всушност, црквата во Тепавци генерално се наоѓa во многу лоша состојба на сочуваност, со отпаднати и распукани фреско-малтери, изложена и деформирана дрвена потконструкција, делумно срушени и напукнати фасади, влага, обраснатост со вегетација, нечистотија, генерална запуштеност односно состојба која, доколку веднаш не се интервенира, наскоро неминовно ќе доведе до нејзино потполно рушење. Покрај институционалната негрижа како основен фактор, причините за оваа состојба се, како впрочем кај доминантен број цркви во руралните подрачја ширум Македонија, од демографски и социјален карактер. Имено, селото Тепавци во текот на XX век речиси целосно се раселува во миграциските процеси, ${ }^{5}$ како кон соседните градови, така и во далечни прекуокеански земји, со што се напушта неговата вернакуларна и сакрална архитектура и се препушта на целосно и неповратно пропаѓање.

\section{Компаративна анализа: неколку ретки примери на поствизантиски трикорабни базилики}

Црквата „Рождество на Пресвета Богородица“ во Тепавци не е единствен примерок на трикорабна базилика датирана во поствизантискиот период, но секако е најдобро и најавтентично сочувана. Имено, во северните краишта на територијата на Македонија среќаваме уште неколку поствизантиски трикорабни базилики, сочувани делумно, односно инкорпорирани во подоцнежни градби или реконструкции.

На падините на Скопска Црна Гора, во нејзините западни разграноци сместени се соседните села Мирковци и Глуво. Во обете села се подигнати цркви посветени на Св. Никола, што ни сведочи за локален култ кон овој светец. Црквата „Св. Никола“ во селото Мирковци (сл. 4а) претставува постара градба обновена во преродбенскиот период, поточно во 1873 година. Станува збор за монументална градба со вкупни димензии 16,8/10,1 m, односно пропорциски сооднос од 1:1,66. Источните делови на црквата, приближно до половина од наосот, се остатоци од поствизантиската базиликална градба, автентично сочувани и мошне умешно инкорпорирани во

\footnotetext{
${ }^{5}$ Според пописите на населението водени во текот на претходниот, XX век, бројот на жители на Тепавци ќе се намали од 454 во 1953 година, на 25 според последниот официјален попис од 2002 година, за да падне на само 5 постојани жители во 2018 година. Слична поразителна статистика може да се проследи и кај многу други македонски села, особено во планинските, поодалечените и поизолираните региони.
} 
подоцнежната, преродбенска црква. ${ }^{6}$ Според овие остатоци, може да се заклучи дека станува збор за трикорабна базилика, датирана широко во XVIXVII век (Велев, 1990, 135), од која се сочувани три пара масивни изsидани столпци, со димензии од приближно 90/90 cm, кои го раздвојуваат наосот на три брода со благо неправилна форма. Интересно е што широчината на трите брода е речиси еднаква, односно централниот брод, чија широчина варира околу $265 \mathrm{~cm}$, ги надминува бочните за само четириесетина сантиметри. Покриен е со полуцилиндричен свод, чија височина достигнува $4,7 \mathrm{~m}$, надвишувајќи ги бочните, засводени со ниски сводови со елиптичен пресек, за $1 \mathrm{~m}$. Меѓусебно столпците се поврзани со полукружни лаци, така што формираат изедначени аркадни низи. На исток, последниот пар столпци се поврзани со помал лак директно со источниот sид, без пиластри и без конзоли. Особено е интересно и специфично решението на необично малата тространа олтарска апсида. Одвнатре таa е сосем благо заоблена, со три полукружни ниши, од кои централната е поголема и има еден тесен прозорски отвор во вид на процеп поставен во подолжната оска. Странично, во бочните бродови се развиваат проскомидија и ѓаконикон, означени со соодветни плитки, а релативно широки ниши - во источниот sид.

Остатоците од постарата црква завршуваат со третиот пар столпци гледано од исток. Вкупните димензии на наосот и растојанијата меѓу сочуваните столпци ни говорат дека првичната градба имала најверојатно уште еден пар столпци кон запад, кои се срушиле од непознати причини. ${ }^{7}$ На запад од последниот постоечки пар столпци се простира делот додаден во XIX век, кој ги носи сите обележја на преродбенската сакрална архитектура, специфични за регионот на Скопска Црна Гора. ${ }^{8}$ Црквата се наоѓa во живо,

\footnotetext{
${ }^{6}$ Сосема е логично да се претпостави дека сегашниот постоечки габарит на црквата е идентичен со нејзиниот автентичен, поствизантиски волумен, а доколку ободните sидови во западните партии на градбата биле целосно или делумно срушени, секако биле надоградени врз постоечките темели како поекономично решение.

7 Знаејќи ги историските прилики во Скопскиот Регион и пошироко, сосема е веројатно големата трикорабна базилика во Мирковци, изградена во XVI-XVII век, да настрадала во Австро-турската војна (1683-1699) и во Карпошовото востание од 1689 година, или при палењето и опустошувањето на Скопје за време на повлекувањето на австриските војски на север, поминувајќи непосредно покрај долните села на падините на Скопска Црна Гора, или пак во репресиите врз македонското население по повторното воспоставување на отоманската власт.

${ }^{8}$ Имено, речиси до самиот раб на западниот пар столпци се протега исклучително длабока галерија, носена на сопствен конструктивен систем од два пара дрвени столбови (со кружен пресек под галеријата и правоаголен над неа) и греди, со кои доследно се наставува постариот концепт на трикорабна базилика. Длабочината на галеријата изнесува $6,5 \mathrm{~m}$ и зафаќа толку голема површина што во западната зона се поставени две независни скалишта, кои водат до катот. Оградата на галеријата кај црквата во Мирковци ја карактеризира конвексно проширување (балкон) во централниот брод, односно конкавни вдлабнувања во бочните бродови, со што се постигнува барокна извиеност на формите својствена за преродбенската архитектура. Оградата е полна, изведена од дрвени штици и мали штички на нивните споеви, без појава на семитранспарентна ограда - мушарабија, со банкина, која тече по целата
} 
активно село и, за жал, е нестручно обновена од страна на црковниот одбор и локалното население во текот на втората половина на XX век. ${ }^{9}$

Црквата „Св. Никола““ во соседното село Глуво исто така се состои од постара источна зона инкорпорирана во објект изграден во преродбенскиот период, поточно во 1855 година (сл. 4б). Постарата базилика е од непознат датум, но сличностите со црквата во Мирковци ни дозволуваат да ја сместиме во истите широки временски рамки: XVI - XVII век. Приближните димензии на црквата во Глуво изнесуваат 11,6/15,7 m, а како и кај Мирковци и Тепавци, и таа има неправилна, трапезна форма на основата. Сепак, за разлика од овие две цркви, пропорцискиот сооднос кај црквата во Глуво изнесува 1:1,35, односно има исклучително нагласена широчина наспроти должината. Тоа се должи на топографијата на теренот која условила, мошне невообичаено, црквата воопшто да нема западен влез.

Од постарата поствизантиска црква е преостанат олтарот и еден пар изsидани масивни столпци, со димензии од 70/80 cm. Решението на апсидата, широчината на олтарот и источниот травеј се речиси идентични со оние кај базиликата во Мирковци. Така, кај црквата во Глуво среќаваме одвнатре целосно рамна, а однадвор тристрана олтарна апсида, мошне мала во споредба со димензиите на источната фасада. Повторно се јавува тесен прозорец во вид на процеп во оската на апсидата. Одвнатре таа е оформена со три полукружни ниши, од кои централната е поширока, а бочните се помали. Од апсидата до зачуваниот источен пар столпци се протега правоаголен травеј засводен со полуцилиндричен свод, чија височина изнесува 5,18 m. Недостасуваат бочните бродови со проскомидијата и ѓакониконот, кои секако се простирале од обете страни на овој травеј аналогно на црквата во Мирковци. Денес, нивните остатоци се недостапни од олтарот, од кој се одвоени со полни зидови, ${ }^{10}$ како и од наосот, бидејќи се наоѓаат зад олтарната преграда, единствено прекината со царските двери. На запад од опишаниот травеј и

нејзина должина од внатрешната страна, а која денес служи за поставување икони. Особено се интересни два декоративно обработени високи постаменти поставени меѓу централниот и бочните бродови, кои ја надвишуваат оградата и служат за поставување на поголеми, еден вид престолни икони.

${ }^{9}$ При оваа обнова сосема се изменети фасадите, со облоги од нови, несвојствени материјали (бетон и армиран бетон, цементни малтери, фасадна тула, декоративен камен), како и прозорците и покривот на објектот, така што денес е невозможно да се согледа автентичниот надворешен изглед на поствизантиската градба.

${ }^{10}$ По аналогија со базиликата во Мирковци, првобитно сегашниот олтарен травеј на црквата во Глуво наместо полни бочни зидови би требало да има пар столпци поврзани со источниот мид на црквата со лаци, преку кои се овозможува комуникација меѓу олтарот, проскомидијата и ѓакониконот. За да се потврди нивното постоење, како и староста на првобитната црква во Глуво (а секако случајот е ист и кај црквата во Мирковци), е неопходно да се преземат посеопфатни истражувања, кои би опфатиле археолошки сондажни истражувања како на теренот околу базиликата, така и на зидовите и сводовите. Имено, кај црквата во Глуво наместа се евидентни постари слоеви живопис под преродбенскиот, чие откривање може да помогне во датирањето на првата фаза од црквата, за која засега немаме потврдени податоци. 
сочуваниот пар столпци се протега преродбенска „реконструкција“ на црквата, решена како трикорабна базилика, која го користи првобитниот габарит и ја следи типологијата на сочуваната постара градба, но со евидентни измени во решението. ${ }^{11}$

На исток од Скопскиот Регион, во Кумановско, среќаваме уште две поствизантиски трикорабни базилики. Црквата „Св. Никола“ во селото Стрезовце, област Жеглигово, претставува поствизантиска градба темелена врз постари остатоци - најверојатно од византискиот период - на нешто поголема црква, за што ни сведочи археологијата на теренот. Датира од самиот почеток на XVII век, а живописана е во 1606 година (Kiel, 1985, 249). ${ }^{12}$ За нејзината изградба дознаваме од добро сочуваниот ктиторски натпис насликан во фреско-техника над влезот, од внатрешната страна, како што било обичај кај византиските и кај поствизантиските храмови. ${ }^{13}$

Црквата во Стрезовце претставува гробишен храм со „хетерогено, речиси сложено просторно решение“" (Машниќ, 2008, 78). ${ }^{14}$ Ја карактеризира

11 Имено, преродбенската базилика користи поинакви материјали: во централниот брод лесен т.н. „лажен“ свод од дрвена конструкција и малтерни премази наспроти масивно изsиданиот свод на поствизантиската првобитна црква, од кој е понизок за 33 $\mathrm{cm}$; двата пара столбови кон запад се изведени во дрво (источниот пар имаат кружен пресек, а западниот квадратен), како и рамната таваница над бочните бродови и нартексот. Кај црквата во Глуво недостасува класична галерија, која е заменета со подигната зона (еден вид нартекс) западно од столбовите со квадратен пресек, со висинска разлика во однос на наосот од $75 \mathrm{~cm}$. Оваа зона, оградена со рамна полна ограда од дрвени штици ја презела улогата на „женска црква“. За разлика од црквата „Св. Никола“ во с. Мирковци, каде што живописот е ограничен на поединечни сцени на бочните мидови и три мандорли на сводот во централниот брод, кај црквата во с. Глуво сводните партии се целосно живописани, и тоа од раката на најголемиот и најславен преродбенски уметник Дичо Зограф (Василиев, 1946, 377), чиј потпис се наоѓа на крајот од долгиот ктиторски натпис, кој тече околу-наоколу централниот свод. Исто така, тој е автор и на десетте престолни икони, царските двери, дванаесетте апостолски икони со деизисната композиција, како и дванаесетте празнични икони.

${ }^{12}$ Сликарството на црквата во Стрезовце, иако делумно сочувано, претставува мошне репрезентативен претставник на уметноста во рамки на Османлиската Империја, односно во поствизантискиот свет. Ангажираните сликари, според Машниќ, потекнуваат од Костурскиот културен ареал, а работеле на повик првин во рамки на Охридската архиепископија, а потоа и во Пеќската патријаршија, односно македонските територии, кои припаднале под нејзина јурисдикција (Машниќ, 2008, 81).

${ }^{13}$ Според овој натпис, изградбата на храмот е резултат на залагањата на презвитерите кир Константин и кир Петко, како и на жителите на Стрезовце, за време на Пеќскиот патријарх Јован $(1592$ - 1614) и скопскиот владика Макариј. Имено, по 1557 година, северните краишта на Македонија, како и голем дел од западните краишта на денешна Бугарија, ќе бидат одземени од диацезата на Охридската архиепископија и присоединети кон обновената Пеќска патријаршија (Kiel, 1985, 222-224) во постепен процес на намалување на нејзината моќ, кој ќе кулминира со целосно укинување во 1767 година.

${ }^{14}$ Во Кумановскиот Регион, поточно во историската област Жеглигово, се среќаваат повеќе цркви, кои припаѓаат на „хетерогена група ирковни градби ... со необични 
трикорабна диспозиција на наосот, со димензии од 10/22 m, во комбинација со впишан крст во правилно квадратно пространство оформено со помош на два пара масивни столпци. Централниот кораб е премостен со полуцилиндричен свод, а бочните, кои се пониски, со четвртина свод. Кон исток, во олтарот се развива една полукружна олтарска апсида. Целата градба е покриена со еден масивен двоводен покрив, без надвишувања, првично прекриен со камени плочи, подоцна заменети со ќерамиди. Градена е со правилно обликувани блокови од камен трахит, специфичен за сакралната архитектура во поширокиот источен регион (Кратовско, Кумановско). ${ }^{15}$ Од западната страна на црквата истовремено е подигната припрата, со исто така трикорабна диспозиција. Подоцна, за жал, сводовите на припратата се урнати, а градежниот материјал искористен за изградба на кула-камбанарија, така што денес припратата е под отворено небо, односно претставува правоаголен ограден простор. ${ }^{16}$

Црквата „Св. Дух“, позната и како „Св. Троица“, претставува трикорабна гробишна црква изградена во селото Добрача, најверојатно на почетокот (првата деценија) од XVII век, односно истовремено со црквата од ист тип во Стрезовце, обете од Кумановскиот Регион. Црквата е видоизменета при реконструкција во 1931 година: сочувани се елементи на камена пластика на западната фасада, а фреско-сликарството е целосно уништено (ХаџиВасиљевиђ, 1909, 442).

Од сето погоре наведено може да се заклучи дека поствизантиските базиликални цркви од регионот на Скопска Црна Гора (во селата Мирковци и Глуво), како и тие од Кумановскиот Регион (во Стрезовце и во Добрача) претставуваат две издвоени групи споменици со свои засебни локални обележја и карактеристики. Црквите од Скопска Црна Гора сведочат за еден

архитектонски решенија“ (Машниќ, 2008, 74). Такви се, на пример, двојната гробишна црква „Св. Никола/Св. Ѓорѓи“ во селото Сув Орах, датирана исто така на самиот почеток од XVII век, како и црквата „Св. Петка“ во селото Мургаш.

15 Понатаму, особена е обработката на прозорските транзени со тантелеста камена пластика во полн релјеф, како локална специфика карактеристична за неколку цркви од истиот регион: црквите во селата Старо Нагоричане („Св. Горѓ́“"), Младо Нагоричане („Св. Ѓорѓи“ и „Св. Петка“) и Жегљане („Св. Ѓорѓи“), кои датираат од византискиот и поствизантискиот период.

16 Како декоративен елемент, лаците над влезовите во припратата се изведени со алтернација на блокови камен со посветла и потемна нијанса, каква што среќаваме и кај челата на трансептот кај црквата „Св. Ѓорѓ Победоносец“ во блиското село Младо Нагоричане (Машниќ, 2008 (Б), 70), која датира од истиот период. Специфично за оваа црква е што во припратата, по должината на јужниот и на северниот sид, биле поставени долги ниски трпези изработени од камен, на кои се собирало локалното население на заеднички оброк при прослави и црковни свечености. По рушењето на сводната конструкција, оваа намена се загубила, а денес трпезите се чуваат под импровизирана стреа по должината на јужниот мид, од надворешната страна. Слични камени трпези се сочувани и крај црквата „Св. Ѓорѓи Победоносец“ во Младо Нагоричане (Машниќ, 2008 (Б), 73), која првично, исто така, имала трикорабна припрата - трпезарија, што повторно ни зборува за едно локално распространето обележје, специфично за жеглиговскиот крај. 
зрел и мајсторски пристап во инкорпорирањето на специфични поствизантиски трикорабни базилики во објекти изградени со преродбенска архитектура прилагодена на затекнатата архитектонска типологија. Кај црквите од Кумановскиот Регион, пак, карактеристичната гробишна намена, како и изградбата врз постари остатоци, придонеле за комплексноста на употребеното некарактеристично типолошко решение. Кај обете групи, нивните евидентни меѓусебни паралели ни говорат за можно авторство во рамките на исти градителски тајфи или пак градење според модел како обележје на припадноста кон локална „градителска школа“. Имено, освен постарата византиска градба врз која е темелена црквата во Стрезовце, секако не смее да се занемари и близината и несомнените влијанија на црквата „Св. Ѓорѓи“ во Старо Нагоричане, која претставува монументална византиска трикорабна базилика, првобитно од XI век, со масивно sидани столпци поврзани со лаци, во која при реконструкција од почетокот на XIV век е вметнато повеќекуполно решение (Серафимова, 2008, 64). Нејзиното влијание врз подоцнежните сакрални објекти од регионот, на пример црквата „Св. Ѓроѓ Победоносец“ во соседното село Младо Нагоричане, го забележале повеќе релевантни автори (Машниќ, 2012, 19-20).

Црквата „Рождество на Пресвета Богородица“ во Тепавци споделува низа заеднички карактеристики со овие неколку трикорабни поствизантиски цркви: релативно мали распони на бродовите, со мошне слични димензии кај сите цркви, масивни димензии на столпците, изедначена поделба на наосот на три речиси еднакви брода како во основа, така и во пресек. Сепак, таа се издвојува од нив како географски, така и по нејзината изградба значително подоцна, во втората половина на XVIII век. Понатаму, ја издвојуваат и карактеристични елементи на архитектурата: три полукружни апсиди, три влезни портали со соодветни отворени тремови, кои не се среќаваат кај другите трикорабни базилики од поствизантискиот период. ${ }^{17}$ Така, за нејзината специфична архитектура е потребно да се бараат дополнителни, географски поблиски извори на влијание, кои несомнено придонеле да биде избрано токму ова архаично решение.

\section{Антецеденти, потекло, влијанија}

Невозможно е да се зборува за потеклото на одбраната базиликална типологија, во случајот на црквата „Рождество на Пресвета Богородица“ во Тепавци, без да се осврнеме на катедралата на Охридската архиепископија, црквата „Св. Софија“ во Охрид (сл. 5), за чија историја, хронологија и

\footnotetext{
${ }_{17}^{17}$ Малечките, однадвор тристрани апсиди, се една од карактеристиките на црквите во Мирковци и во Глуво, кои ги поврзуваат директно со современите поствизантиски еднокорабни црквички, каде што преовладува ова решение. За разлика од нив, црквата во Тепавци, со своите три полукружни апсиди, секако настанала под други, локални влијанија.
} 
архитектонска типологија во науката е пишувано обемно. ${ }^{18}$ Охридската катедрала е, имено, мошне сложена градба, градена и доградувана во повеќе наврати уште од римскиот и ранохристијанскиот период. Сепак, најзначајна е нејзината средновизантиска фаза ${ }^{19}$ - трибродна базилика од т.н. „преоден тип“, надополнета со специфични катни капели во бочните бродови, така што централниот брод и трансептот формираат крстовиден волумен во чие средиште се издига купола, како и нартекс на кат со пристап преку скалишна кула. Наосот ${ }^{20}$ е разделен на три брода, чиј сооднос изнесува 2:1, со помош на четири пара масивни столпци, поврзани со широки лаци меѓу себе, односно со пиластри на западниот и на источниот sид (сл. 5). На исток, трите брода завршуваат со апсиди: бочните, помали апсиди имаат полукружна основа, каква што среќаваме и кај источниот пар спратни капели, додека централната висока апсида е полигонално решена, со три независни прозорски отвори од типот монофора (сл. 6б). Во наосот се пристапувало преку три влезни портали, поставени во симетрична композиција: во оската на трансептот на обете бочни фасади, како и на запад, преку нартексот, сите три првично заштитени со отворени тремови/портици. Подоцна, на почетокот на XIV век, оваа сложена композиција е надополнета со монументален двоспратен ексонартекс.

Секако, во XVIII век, односно во периодот на изградбата на црквата во Тепавци, „Св. Софија“ веќе имала мошне видоизменета архитектура: при нејзината конверзија во џамија, во XV-XVI век, е извршена темелна реконструкција на наосот, при што е срушена сложената конструкција од трансепт и купола, како и западниот пар спратни капели и е заменета со класична трибродна диспозиција, со полуцилиндрични сводови над бочните и надвишен свод над централниот брод (сл. 5). Целосно е затворен јужниот влезен портал, а доминантна улога добива северниот, за која цел, со реутилизација на автентичен градежен материјал по должината на северната фасада, е изграден отворен трем. Целокупниот наос, без надвишување на централниот брод, е покриен со еден масивен двоводен покрив, како што е случај и кај двата нартекса. Токму оваа фаза од градителската историја на „Св. Софија“, која им била всушност достапна на мајсторите - градители во XVIII век, може да се препознае кај црквата „Рождество на Пресвета Богородица“ во

\footnotetext{
18 Детален преглед на постара библиографија кај КОРАЋ, В. (2008). „Света Софија у Охриду, простор, структура, облици. Извори“. Зограф 32. Београд: Филозофски факултет, 29-35. и, се разбира, кај ЧИПАН, Б. (1996). Св. Софија: катедрален храм на Охридската архиепископија. Скопје: Сигмапрес, Универзитет „Св. Кирил и Методиј“, Архитектонски факултет.

${ }^{19}$ Покрај оваа најзначајна катедрална црква на Охридската архиепископија, периодот на X-XI век ќе го одбележат уште неколку базиликални градби, денес сочувани на ниво на археологија: „Св. Ахил“ на истоимениот остров во Мала Преспа; „Св. Богородица“" во Враништа, Струшко; базиликата во Мородвис (Кочани); постарата (источна) црква од манастирскиот комплекс Водоча (Струмичко); како и црквата во Велушина, Битолско, за која овде ќе стане збор.

${ }^{20}$ Приближните димензии на наосот, без апсидите, нартексот и без придружните простории, изнесуваат 17/24 m.
} 
Тепавци (сл. 6), како во формата и димензиите на столпците и нивниот ритам, така и во сводовите, тројната диспозиција на олтарот со апсидите - како и прекривањето на целиот споменик со единствен масивен покрив на две води.

Понатаму, одредени влијанија можеле да пристигнат во Тепавци и од географски блиската монументална црква „Св. Никола“ во селото Манастир, Прилепско Мариово, ${ }^{21}$ „подигната од темел“ од страна на игуменот Акакиј во 1266 година врз постара црква од XI век и живописана во 1271 година (Серафимова, 2008 (Б), 140). Станува збор за компактна трикорабна базилика (сл. 8), ${ }^{22}$ со неправилна (трапезна) основа, без нартекс, со масивни столпци и пиластри, кои го носат сводот над надвишениот централен брод, додека пониските бочни бродови се покриени со рамни дрвени таваници. На исток, сите три брода завршуваат со високи тристрани апсиди, расчленети со по три слепи ниши и монофори кај бочните, а бифорален прозорец во оската на централната олтарска апсида. Високо на источната и на западната фасада се наоѓаат прозорски отвори со транзена од камена пластика обликувана во вид на крст - четирилисна детелина (crux florida).

За разлика од поствизантиските трикорабни базилики, вклучително и црквата во Тепавци, кај „Св. Никола“ во Манастир, централниот брод е значително поширок (соодносот е приближно 2:1) и повисок од бочните. Понатаму, масивните столпци и арките меѓу нив имаат речиси еднакви димензии, со изедначен ритам на празно наспроти полно. ${ }^{23}$ Сепак, нејзиното влијание во поширокиот Мариовски Регион не смее да се занемари; како од аспект на самата доследна примена на необична, архаична базиликална типологија, така и во одредени архитектонски елементи, како што се трите олтарски апсиди, прозорските отвори со транзени од камена пластика и т.н.

Исто така, не смее да се занемари и улогата на црквата „Успение на Пресвета Богородица“ во селото Велушина, Битолско, ${ }^{24}$ кај локалното население позната како „Стара црква“, која претставува исклучително сложен споменик, граден во неколку фази на древно култно место (сл. 7). Според археолошките истражувања, најстариот објект бил трибродна, а можеби и

\footnotetext{
21 Црквата „Св. Никола“ во Манастир е единствена доцновизантиска трикорабна базилика во Македонија, градена под силно влијание на базиликалните градби од периодот на нивниот процут (X - XI век): „Св. Ахил“ на Преспа и „Св. Софија“ во Охрид, кои секако претставуваат еден вид прототип за поширокиот регион, подоцна преземен од неколку мали базиликални црквички во Костур („Св. Стефан“, „Св. Архангели““, „Св. Врачи“), Плиска, Преслав и Мелник (Коруновски и Димитрова, 2006, 86-87). Сепак, во своето инаку архаично решение инкорпорирала современи обележја од периодот кога настанала, особено во третманот на фасадите со низи од помали слепи ниши, нивното насликување и применетиот фасаден опус.

22 Димензиите на наосот изнесуваат приближно 13/16 m, без олтарските апсиди.

${ }^{23}$ Како што е случај кај постарите храмови „Св. Ахил“ на Преспа, базиликата во Враништа, Струшко (Бошковиќ, 2000, 47) или пак Старата Митрополија во Несебр (Бугарија), под чие влијание настанала.

24 Лоцирана е на југоисточната страна на селото, на десниот брег на Остречка Река, во близината на стариот римски пат Via Egnatia, односно делницата што водела од ранохристијанската епископија Heraclea Lyncestis кон југ.
} 
повеќебродна базилика од периодот на доцната антика - раното христијанство, поточно V век (Михајловски, 2011, 143-144). ${ }^{25}$ Понатаму, следната фаза настапува во IX - XI век, односно средновизантискиот период, кога е реконструиран нартексот и целиот објект добива ,ретардиран покрив на две води“ (Ibid, 146), а од овој период - раниот XI век - датира и делумно сочуван живопис. Како што дознаваме од пишани извори, црквата е обновена и пресликана од страна на јеромонах Гаврил од Костур во 1792 година (приближно истовремено со црквата во Тепавци!), период од кога датира и иконостасот, а денешниот изглед го добива во 1836 година, кога била и целосно живописана. ${ }^{26}$

Денес, црквата во Велушина е трибродна базилика, ${ }^{27}$ со сооднос на централниот наспроти бочните бродови од 2:1. Од првичните трибилони, ${ }^{28}$ преку кои бродовите комуницирале меѓусебно и со нартексот, изворно е сочуван западниот; делумно северниот, каде што е поставен амвон; додека кај јужниот недостасуваат столбовите, а на средина дополнително е изsидан столбец. На исток, постои директна врска меѓу олтарот и проскомидијата и ѓакониконот, првично одделени од наосот со мермерна олтарна преграда, денес фрагментарно сочувана. Бочните (полукружни) апсиди се сочувани само во археологија, додека централната мошне висока полукружна апсида со декоративно обработен трифорален отвор со мермерни меноа - е неколкупати преsидувана, судејќи по нејзината сложена стратиграфија. Слично конципиран бифорален прозорец со мермерно мено е сочуван високо на западната фасада. Во горната зона, автентичната сводна конструкција недостасува, а во поскорешните реконструктивни зафати од XVIII-XIX век била заменета со рамна дрвена таваница. Во храмот се влегува преку западен и јужен влезен портал, заштитени со отворен трем на јужната, а затворен на западната страна, но во неговата првична диспозиција мошне веројатно е да имал тремови и влезни портали од сите три страни.

Евидентно е дека еден волку стар и значаен споменик влијаел на архитектурата на подоцнежните црковни градби во околината, особено во

\footnotetext{
${ }^{25}$ Според сочуваните остатоци може да се заклучи дека „базиликата во Велушина е инспирирана од базиликите во Солун од петтиот век, посветени на Богородииа Ахиеропоитос и свети Димитриј. Базиликалната градба се состои од три брода одделени со кидови, кои се отворени со ритмичко поставени трибилони и на исток завршуваат со апсиди. “ (Михајловски, 2011, 144). За најстарите градбени фази на велушката базилика ни сведочи богатство археолошки наоди употребени како сполии, или пронајдени во внатрешноста на храмот и во неговата околина.

26 Живописот е пресликан од работилницата на Јован од Трново, влашки зограф по потекло од Епир, кој во 1845 ја насликал и манастирската црква „Св. Ѓорѓи“ во истото село. Како автор на дел од иконите се јавува Димитрие Андонов, зограф од потпелистерското село Магарево.

27 Димензиите на наосот, без олтарската апсида и подоцна додадените тремови, изнесуваат 13,7/16,6 m.

${ }^{28}$ Сочуван слично конципиран трибилон среќаваме и на спратот од нартексот кон централниот брод кај катедралната црква „Св. Софија“ во Охрид, од нејзината фаза од XI век.
} 
периоди кога и самиот бил предмет на одредена обнова, како што е токму XVIII век. Иако сложениот внатрешен концепт на црквата „Успение на Пресвета Богородица“ во Велушина можеби не послужил како директна инспирација за црквата во Тепавци, реминесценција на нејзината надворешна артикулација, особено што се однесува до источната фасада со три полукружни апсиди, и тоа како може да се препознае.

Од сето погоре изнесено можеме да заклучиме дека црквата „Рождество на Пресвета Богородица“ во Тепавци, Битолско Мариово, претставува мошне значаен репрезент на исклучително ретко застапената типологија на монументални трикорабни базилики од поствизантискиот период, какви што уште среќаваме во Скопскиот и Кумановскиот Регион. Со овие нешто постари цркви споделува неколку суштински заеднички карактеристики (димензии и распоред на столпците од аркадните низи, сооднос на централниот наспроти бочните бродови, како и слични вкупни пропорции на храмот, еден масивен покрив на две води), но сепак се разликува во артикулацијата на источната фасада со три полукружни апсиди, како и со употребените транзени од камена пластика со крстовидни мотиви. Овие елементи ја поврзуваат со неколку исклучително значајни постари базиликални градби од регионот: „Св. Софија“ во Охрид, „Св. Никола“ во Манастир и „Успение на Пресвета Богородица“ во Велушина, градени во повеќе фази, но пред сѐ во средновизантискиот период за кој е специфично навраќање кон архаичните базиликални обрасци во сакралното градителство, по што трикорабната базилика целосно се напушта за повторно да „воскресне“ за време на преродбата. Токму затоа, црквата во Тепавци, заедно со преостанатите неколку поствизантиски трикорабни базилики, претставува извонредно значаен споменик, алка која ги поврзува преродбенските базилики масовно градени по должината на следниот XIX век со нивните средновизантиски, а посредно и ранохристијански антецеденти доказ дека монументалните базиликални решенија, и покрај општествените услови за време на Отоманската Империја, не биле заборавени, туку опстоиле во колективната меморија и продолжиле да се негуваат, иако спорадично, како алатка за идентификација со најсветлите епохи од минатото. Во случајот на црквата во Тепавци, нејзиниот придонес како клучна алка во еволутивниот развој на трикорабната базилика на овие територии е особено значаен: од една страна нејзината основна архитектонска лексика, архаичниот призвук на внатрешниот волумен со: тешки, масивни, релативно ниски столпци и трипартитното олтарно пространство ја врзуваат директно со средновизантиските прототипови. Од друга страна обликот на покривот со карактеристични дополнителни две води на пократките фасади, оформувањето на влезните портали, а пред сѐ материјалот од кој се изведени лажните сводови, директно ја поврзуваат со преродбенските базилики, со што таа станува нивен вистински предвесник. 


\section{ЛИТЕРАТУРА}

БОШКОВИЌ, Ѓ. (2000). „Средновековната архитектура во Македонија“. Во Архитектурата на почвата на Македонија. Прилози за истражувањето на историјата на културата на почвата на Македонија, книга 9, МАНУ, Скопје, 45-58.

ВАСИЛИЕВ, А. (1946). „Дичо Зограф“. Македонска мисъл кн. 7-8, София, 372-384.

ВЕЛЕВ, И. (1990). Преглед на средновековни иркви и манастири во Македонија. Скопје: Наша книга.

ЃОРЃИЕВ, В. (2013). „Македонија во османлискиот период“. Во Македонија. Милениумски културно-историски факти, том 4, МПМ, Скопје, 1869-1956.

KIEL, M. (1985). Art and Society of Bulgaria in the Turkish Period. Assen / Maastricht: Vim Gorcum.

КОРУНОВСКИ, С. и ДИМИТРОВА, Е. (2006). Византиска Македонија. Историја на уметноста на Македонија од IX до XV век. Скопје: Детска Радост.

МАШНИЌ, М. (2008). „Свети Никола, с. Стрезовце крај Куманово“. Во Македонско културно наследство. Христијански споменици, Скопје, 78-81 (A).

МАШНИЌ, М. (2008). „Свети Ѓорѓи Победоносец, с. Младо Нагоричане крај Куманово“. Во Македонско културно наследство. Христијански споменици, Скопје, 70-73 (Б).

МАШНИЌ, М. (2012). „Зидно сликарство цркве Св. Ђорђа Победоносца у Младом Нагоричину“. Зборник Матице срспке за ликовне уметности 40, Нови Сад, $19-40$.

МИХАЈЛОВСКИ, Р. (2011). „Од духовното наследство на Via Egnatia: црквите Успение на Пресвета Богородица од Велушина и Богородица Пречиста од Граешница“. Патримониум.мк година 4, бр. 9, Скопје, 141-156.

ПАЛИГОРА, Р. (2011). Студија за поврзуване $и$ промоиија на манастирскиот туризам на Баба Планина. Битола: Центар за развој на пелагонискиот плански регион.

СЕРАФИМОВА, А. (2008). „Свети Ѓорѓ, с. Старо Нагоричане крај Куманово“. Во Македонско културно наследство. Христијански споменици, Скопје, 64-69 (А).

СЕРАФИМОВА, А. (2008). „Свети Никола - Манастир, с. Манастир, Мариово крај Прилеп“. Во Македонско културно наследство. Христијански споменици, Скопје, 140-143 (Б).

СНЕГАРОВ, И. (1946). „Възстановяване на Охридската Архиепископия“. Македонска мисъл кн. 7-8, София, 335-343.

ЌОРНАКОВ, Д. (1987). „Развојниот пат на резбарството во Македонија“. Културно наследство X-XI (1983-84), Скопје, 5-33.

ХАЏИ-ВАСИЉЕВИЪ, Ј. (1909). Јужна Стара Србија 1, Кумановска област. Београд: Задужбина И. М. Коларца. 
Emilija Apostolova Chalovska

\title{
THE CHURCH "BIRTH OF THE MOST HOLY VIRGIN" IN TEPAVCI: A POST-BYZANTINE ANTECEDENT OF THE RENAISSANCE THREE-NAVE BASILICAS
}

\begin{abstract}
Summary
The XIX century was marked by a thorough renaissance of the society within the Ottoman Empire, especially its European territories. In the spirit of romanticism, an old, long forgotten architectural typology - the three-nave basilica, resurged as a symbol of a glorious past. Namely, three-nave basilicas were common in Macedonia during the reign of Samuil (X-XI century), i.e. the middle byzantine period, followed by centuries of abandonment in favor of other typologies which were dominant up until the XIX century renaissance movement. This is especially evident after the fall of the Byzantine Empire, when the local Christian community lost all previous privileges, allowing only for the construction of small, rural temples and remote monasteries. In that context, the appearance of several archaic three-nave basilicas dating from the XVI-XVIII century is particularly important, for they represent a link between the middle-byzantine prototype and the resurgence of the renaissance basilicas eight centuries later.

The best preserved example of these post-byzantine basilicas is the church of the "Birth of the Most Holy Virgin", built in 1767 in the small village of Tepavci, region of Mariovo. In addition to the analysis of its architecture, iconostasis and fresco-decoration, the emphasis in the paper is put on the truly unique blend of archaic forms and architectural elements (three apses, three vaulted naves separated by sturdy, massive columns) and new contemporary introductions ("false" vaults constructed out of wood, one massive roof without a protruding central nave, which will contribute later to these type of basilicas being referred to as "hallenkirche" - hall churches). The second part of the paper is dedicated to a comparative analysis with the other, partially preserved postbyzantine basilicas (the churches in Mirkovci, Gluvo, Strezovce and Dobracha) in an attempt to identify the similarities (the proportion of the naos in general and the three naves in particular, the shape, dimensions and rhythm of the columns and the arches that connect them) and differences (especially in the altar, as well as the very nature of the vault structure). This comparison leads to the conclusion that, while all post-byzantine basilicas share certain similarly designed and executed elements, the Tepavci church displays other architectural traits obviously influenced by other, older monuments found in its geographical proximity. The last part of the paper, thus, sheds a light on the influence of several very important middle-byzantine churches ("St. Sophia" in Ohrid and the churches in the villages of Manastir and Velushina).

In conclusion, however restrictive the Ottoman society may have been, the basilical typology and its symbolism were never entirely forgotten; they persevered in the collective memory from which they, albeit sporadically, resurged as a tool for identification; an evolution process which will inspire the construction of hundreds such basilicas throughout Macedonia and the Balkans during the XIX century revival, to which the Tepavci basilica represents a key antecedent.
\end{abstract}




\section{Илустрации}

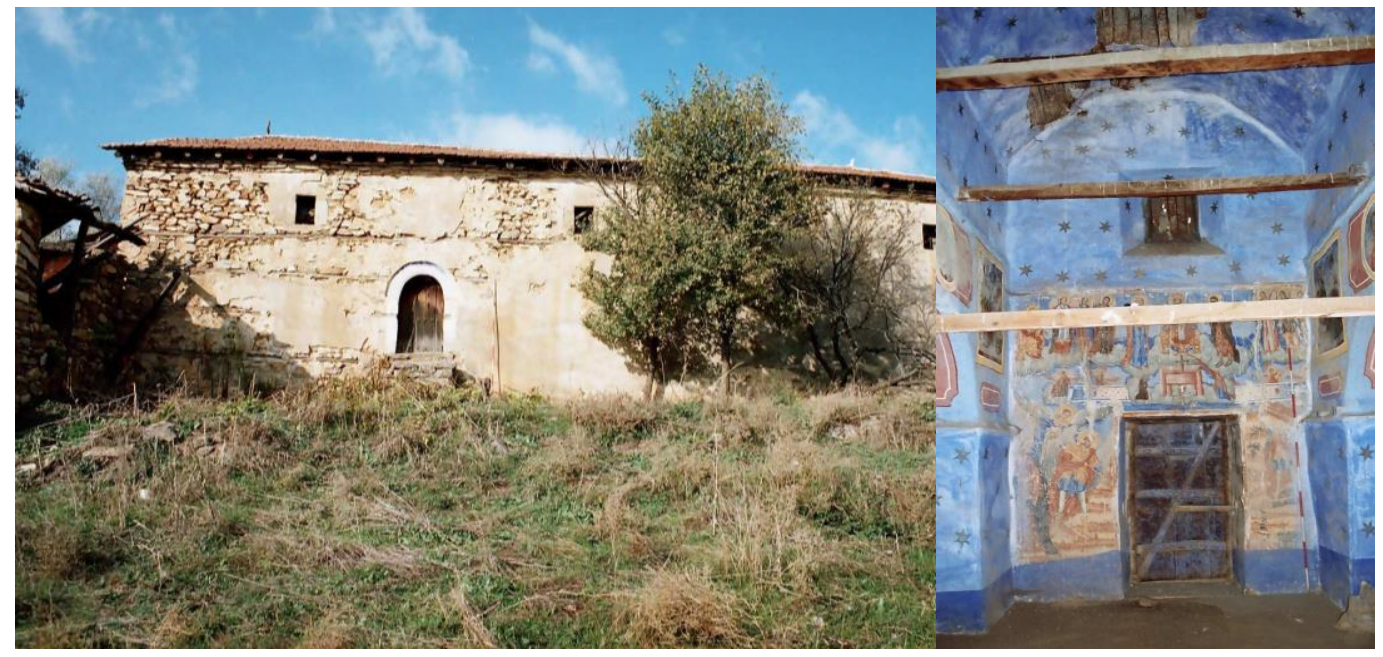

Сл. 1. Црквата „Рождество на Пресвета Богородица““ во Тепавци. а) поглед од југ, извор: mojrodenkraj.com.mk; б) внатрешност, извор: документација на НУ Завод и музеј - Битола.

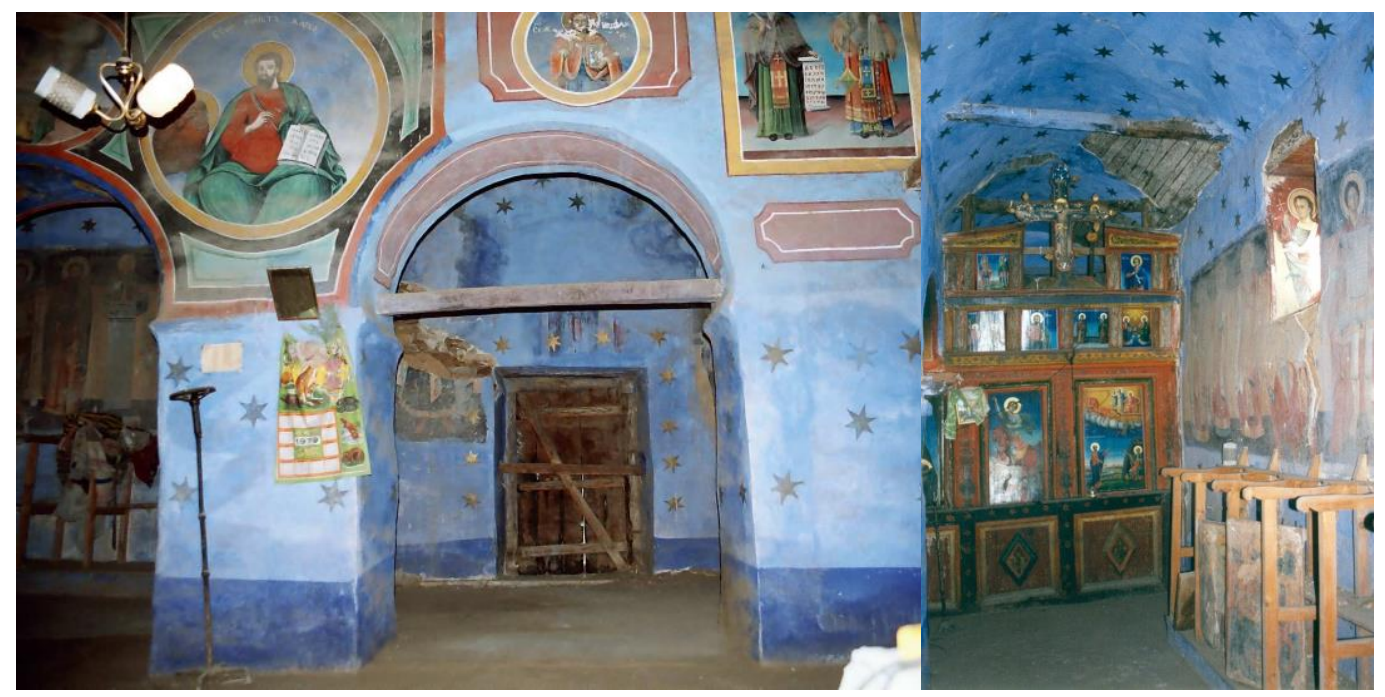

Сл. 2. Внатрешност на црквата „Рождество на Пресвета Богородица“ во Тепавци. Извор: документација на НУ Завод и музеј - Битола. 

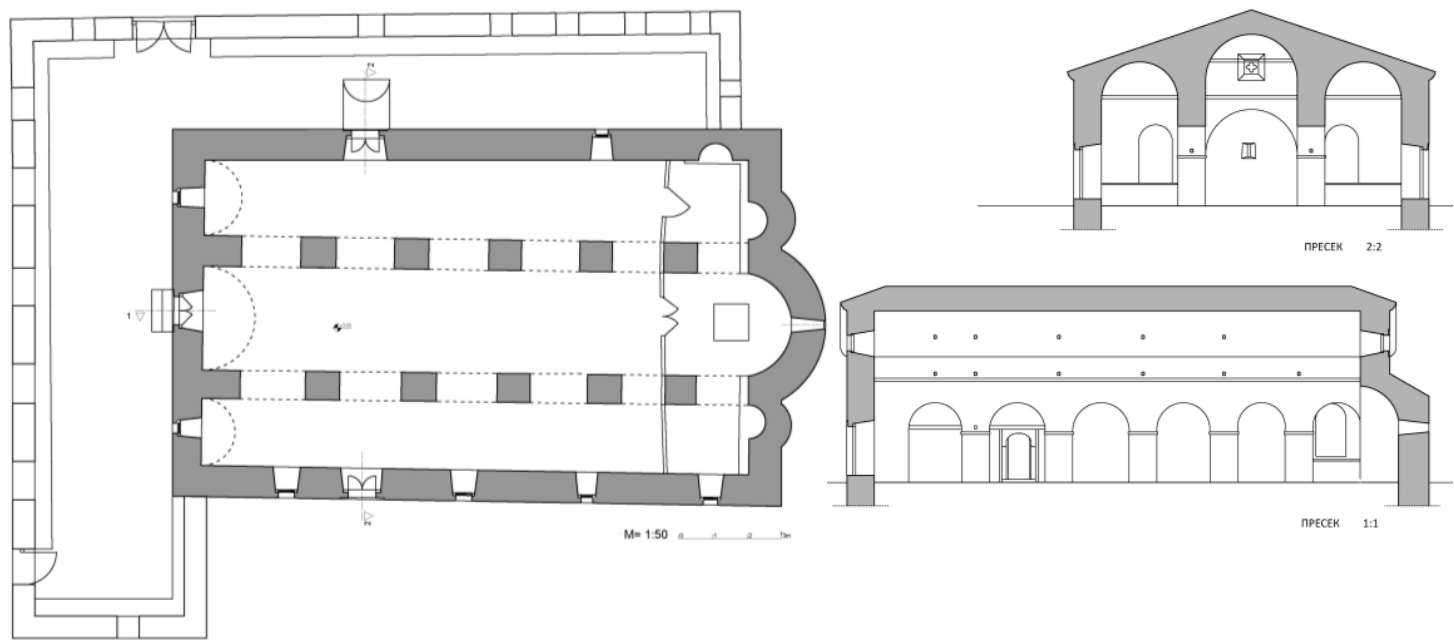

Сл. 3. Основа, напречен и надолжен пресек на црквата „Рождество на Пресвета Богородица“ во Тепавци. Извор: авторот, преземено и прилагодено од документација на НУ Завод и музеј - Битола.
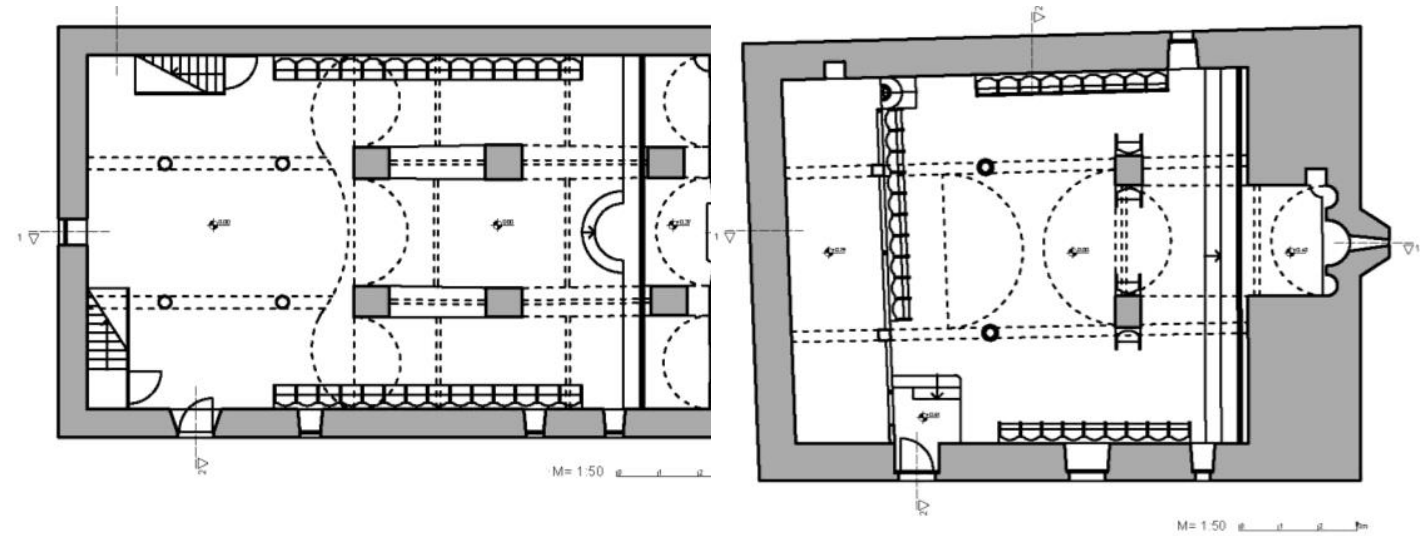

Сл. 4. Основа на црквите а) „Св. Никола“ во Мирковци и б) „Св. Никола“ во Глуво. Извор: авторот. 

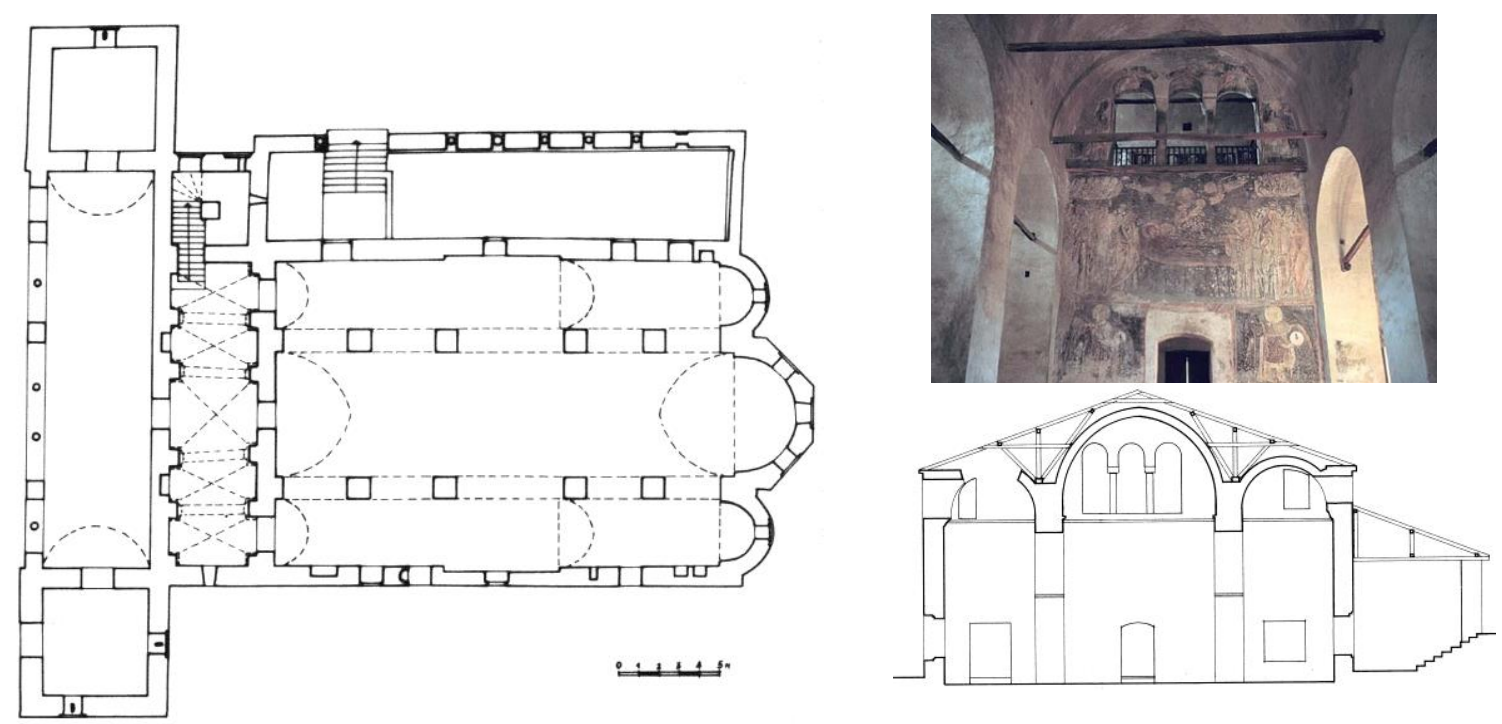

Сл. 5. Црквата „Св. Софија“ во Охрид по турската реконструкција.

а) основа и

б) наос, поглед кон запад и попречен пресек. Извор: авторот.

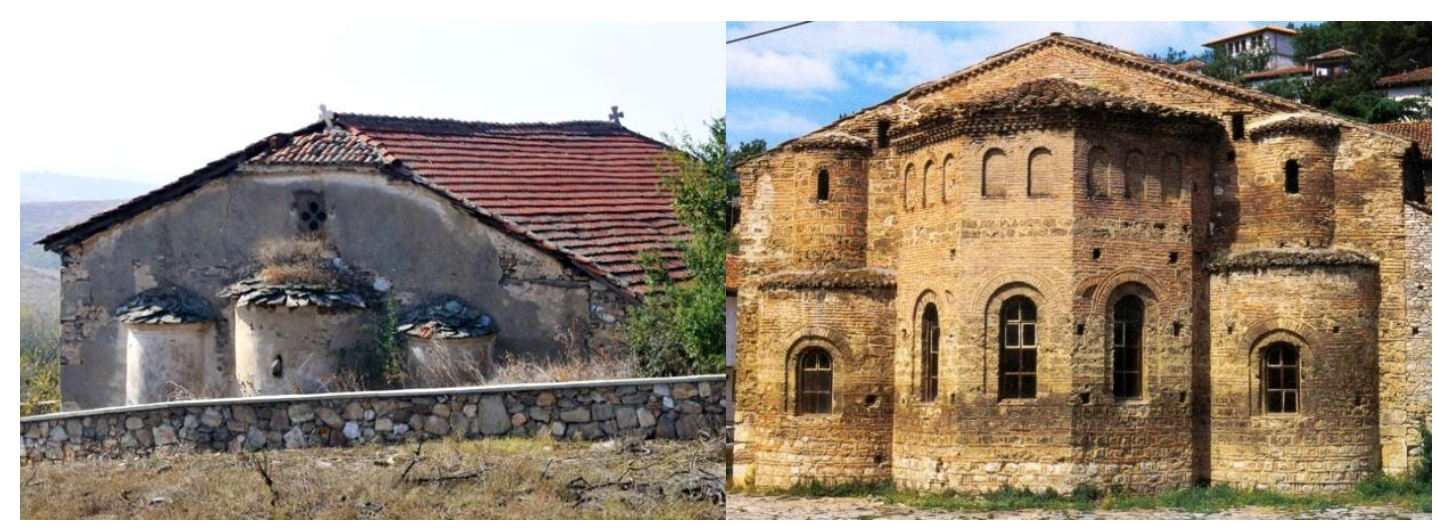

Сл. 6. Компарација на источните фасади со 3 апсиди а) црквата „Рождество на Пресвета Богородица“" во Тепавци, извор: mojrodenkraj.com.mk и б) црквата „Св. Софија“ во Охрид, извор: Коруновски и Димитрова, 2006. 


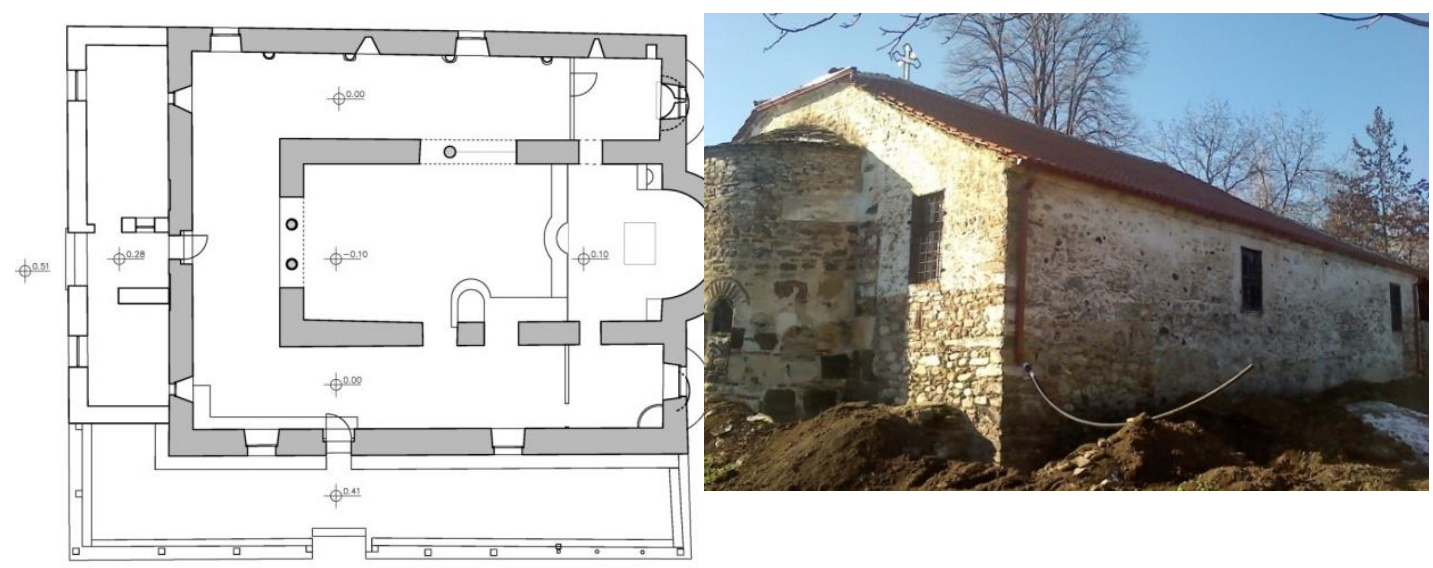

Сл. 7 Црквата „Успение на Пресвета Богородица“ во Велушина а) основа и б) поглед од североисток. Извор: авторот, преземено и прилагодено од документација на НУ Завод и музеј - Битола.

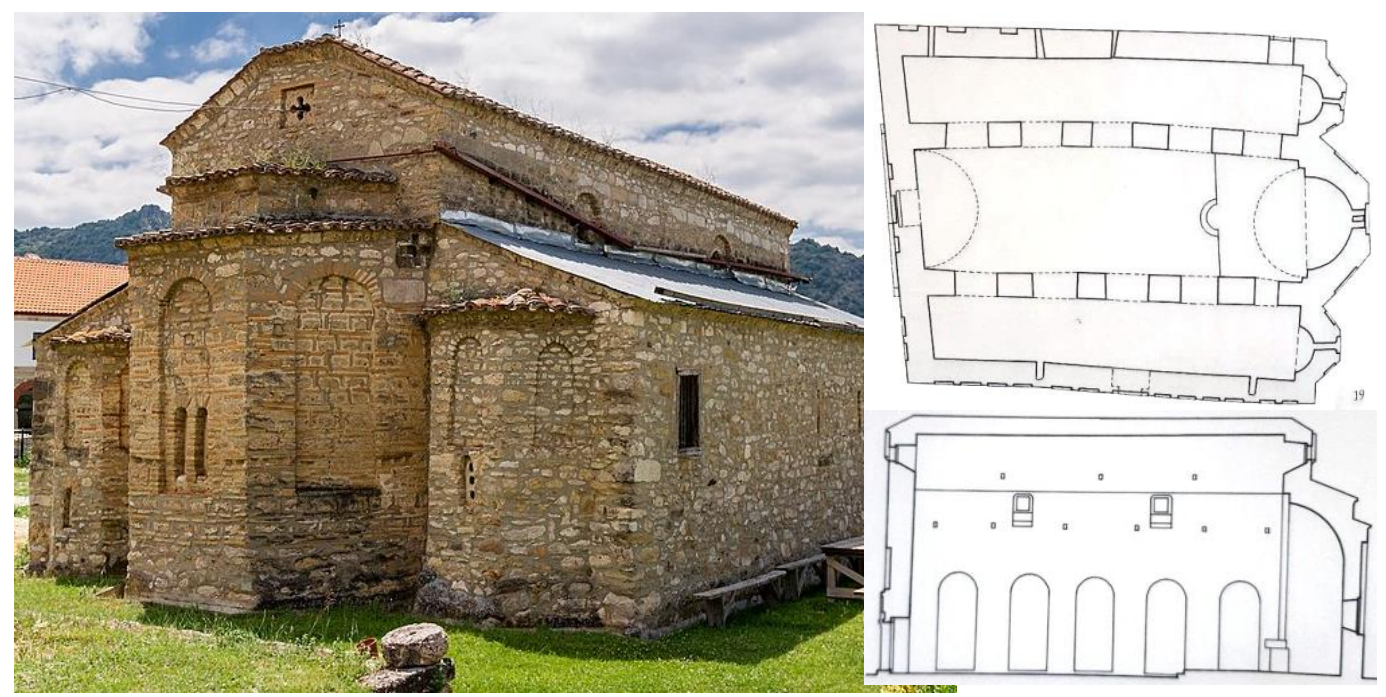

Сл. 8 Црквата „Св. Никола“ во Манастир а) поглед од североисток, извор: wikipedia.org и б) основа и надолжен пресек, извор: Коруновски и Димитрова, 2006. 